\title{
A NEW OVERVIEW OF THE GENUS MYCOBACTERIUM
}

Aninda Sen ${ }^{1}$.

1. Professor, Department Of Microbiology, Katihar Medical College, Katihar, Bihar, India.

\section{CORRESPONDING AUTHOR:}

Aninda Sen,

Department of Microbiology,

Katihar Medical College,

Katihar - 854 105, Bihar,India.

Email-aninda_0428@yahoo.com

\section{HOW TO CITE THIS ARTICLE:}

Aninda Sen. "A New Overview of the Genus Mycobacterium". Journal of Evolution of Medical and Dental Sciences 2013; Vol2, Issue 26, July 1; Page: 4676-4681.

ABSTRACT: It is generally believed that mycobacteria are warm blooded host-adapted pathogens which are very fastidious organisms and cannot live independently in nature as saprophytes. However, recent information on many newer types of mycobacteria shows that the opposite may be true, i.e., a vast majority may be free-living in the environment's soil and water. Others are environmental ones which have learnt to adapt to various plants and animal life-forms including humans. Only few, possibly, are partly or wholly adapted to become human or animal pathogens. This novel evolution of the mycobacteria makes us present this data on ecology, metabolism and pathogenicity of the genus Mycobacterium to substantiate this position.

KEYWORDS: Mycobacterium, Saprophyte, CAN bacteria, parasite, host-adapted facultatively pathogenic

INTRODUCTION: Although it was initially thought that mycobacterium are essentially host-adapted and pathogenic in nature, recent findings have shown that a large number of mycobacterium actually exist which are not only freely available in nature but are normally never seen to appear as an animal pathogen. In fact the mycobacterium may actually be classified on the basis of its distribution in nature.

\section{MATERIALS AND METHODS:}

BACTERIAL STRAINS STUDIED: The Mycobacterial Species studied included: $M$. kansasi, $M$. marinum, M. gastri, M. nonchromogenicum, M. terrae, M. gordonae, M. scrofulaceum, M. avium, $M$. xenopi, M. fortuitum, M. smegmatis, M. phlei, M. aurum, M. neoaurum, M. vaccae, M. chelonae, $M$. thermoresistible, M. aichense, M. chubense, M. flavescens, M. komossence, M. obuense, M. parafortuitum, M. sphagni, M. chubuense, M. flavescens, M. komossence, M. obuense, M. parafortuitum, M. sphagni, M. tokoaiense, M. fallax, M. austroafricanum, M. diernhoferi, M. pulveris, M. leprae. 


\section{ORIGINAL ARTICLE}

ISOLATION AND CULTIVATION OF MYCOBACTERIA: Environmental mycobacteria were primarily isolated from the soil and water. For the purpose standard isolation techniques were followed as described by Cruickshank et al., 1975; Lawrence et al., 1986; Banerjee et al., 1989; Parker et al., 1990; Kamala et al., 1992; Portaels et al., 1992; Chakrabarty et al., 1988; Sen, 1999.

RESULTS AND CONCLUSION: The findings (Tables 1-4) suggest that a large number of mycobacteria can be isolated from the soil and water. This shows that most mycobacteria can be isolated from the soil and water. This shows that most mycobacteria may actually be free-living in the environment's soil and water. Based on this, the mycobacteria can actually be classified depending upon their natural habitat. The first group (Table 1) of mycobacteria would be those which are essentially environmental in nature and rarely (if ever) find their way into an animal host. This group of mycobacteria would, therefore, comprise of those which show no pathogenicity in animals and are freely found in nature. Some of these bacteria may be present superficially on animal tissues, mostly as casual residents but are never associated with any disease. The armadillo, for example, is naturally infected with leprosy, but can in addition to the leprosy bacillus, harbour several other types of environmental mycobacteria without being affected with any kind of disease. This group of mycobacteria may be enlisted as in Table 1. It is clear from their habit that they are almost exclusively saprophytic in nature and exhibit free environmental existence.

The other extreme of the mycobacteria in terms of their habitat are the pathogenic ones, which frequently attack such hosts as rats, guinea pigs, mice and even humans. These are transmitted not only from the environment to the host, but also from one warm-blooded host to another. These species are normally species - specific and gets transmitted from one host to another if they belong to the same species (viz. The bovine strains of $M$. tuberculosis, that is specific to the cattle species alone). These bovine mycobacteria appear to be totally parasitic in nature and have hardly any non-pathogenic or saprophytic existence. Such mycobacteria can be listed as in Table 2 .

Between these two poles of mycobacteria is a group which may normally be environmental but can facultatively adapt to warm blooded pathogenic existence. These mycobacteria vary in the extent of pathogenicity and can be broadly grouped into two types. The first type (Table 3 ) is those mycobacteria which are environment-host adapted, and normally occupies superficial surfaces of the host without actually causing any disease. These bacteria can easily reach host surfaces, organs and tissues, but very rarely cause pathogenicity.

The last group (Table 4) is that of those mycobacteria which reach host surfaces easily but cause infections in the host under immuno-suppressed or immuno-compromised conditions of the host only. These mycobacteria can be said to be opportunistic in the sense that they become facultative pathogens rather than being obligate ones. This suggests that under normal immunological conditions the mycobacteria, even if present, would not remain pathogenic at all and would normally be discouraged by the normal human immune system. In immuno-suppressed hosts, as may arise under operative or postoperative situations or under conditions where the patient is suffering from some immunological defect, such as in the case of AIDS patients, these bacteria would become facultatively active and pathogenic as well.

DISCUSSION: The above findings suggest that the earlier supposition that all mycobacteria are warm blood host-adapted pathogens is probably quiet inaccurate and a large number of 
mycobacteria exhibit independent saprophytic existences in nature. In fact possibly only a few, in a small minority of species, are partly or wholly adapted to become human or animal pathogens.

The findings suggest that the environment forms the major reservoir of mycobacteria. Most of these mycobacteria appear to be purely environmental and are not animal adapted. It is only under conditions of suppressed immunity in the hosts that they become capable of showing any degree of pathogenicity. This suggests an environmental origin of mycobacteria. While most of these mycobacteria have continued to remain environmental, a small number of species amongst them appear to have diverted to adapt them to a partially or wholly pathogenic host dependent existence.

Thus, while these two groups form the extremes of adaptation of mycobacteria, some bacteria occupy an evolutionary position in between the two. These constitute the hostenvironment adapted species which invade animal and human tissues but reside in them only casually, without being associated to any disease. This second group also includes those mycobacteria which become pathogenic only facultatively, rather than in an obligate manner, under opportunistic conditions in immuno-compromised and immuno-suppressed hosts.

Besides, these mycobacteria, like all other bacteria, are also constantly undergoing mutations in nature. It is therefore logical to assume that some of these environmental bacteria may undergo mutation that has, over the course of time, rendered some of the vast majority of environmental saprophytic mycobacteria pathogenic. Mycobacterial strains that otherwise would have been harmless, have thereby been rendered pathogenic and may cause disease in humans and animals. If these mutant strains / species of mycobacteria encounter an immuno-suppressed host, the chances of infection in the host would increase several folds. 
TABLE 1: The environmental, primarily saprophytic, mycobacteria

\begin{tabular}{|c|c|c|c|}
\hline $\begin{array}{l}\text { Sl. } \\
\text { No. }\end{array}$ & $\begin{array}{l}\text { Mycobacterium } \\
\text { spp. }\end{array}$ & $\begin{array}{l}\text { Normal Ecosystem / } \\
\text { Habitat }\end{array}$ & Pathogenicity \\
\hline 01 & $\begin{array}{l}\text { M. } \\
\text { nonchromogenicum }\end{array}$ & Soil & $\begin{array}{l}\text { Persists in mouse tissue without } \\
\text { pathogenicity } \\
\text { None in humans }\end{array}$ \\
\hline 02 & M. smegmatis & $\begin{array}{l}\text { Mouse spleen. } \\
\text { Once common in soil \& } \\
\text { water, now infrequent. }\end{array}$ & None in humans \\
\hline 03 & M. phlei & $\begin{array}{l}\text { Once free living in nature, } \\
\text { viz. Hay \& Grass, now } \\
\text { infrequent. }\end{array}$ & None in humans \\
\hline 04 & M. neoaurum & Soil & $\begin{array}{l}\text { Not known to be normally associated } \\
\text { with any disease }\end{array}$ \\
\hline 05 & M. vaccae & $\begin{array}{l}\text { Lacteal glands of cattle } \\
\text { Soil, watering ponds \& wells. }\end{array}$ & $\begin{array}{l}\text { Not known to be normally associated } \\
\text { with any disease }\end{array}$ \\
\hline 06 & M. chubuense & Garden soil & $\begin{array}{l}\text { Not known to be normally associated } \\
\text { with any disease }\end{array}$ \\
\hline 07 & M. komossense & $\begin{array}{l}\text { Sphagnum vegetation in } \\
\text { bogs }\end{array}$ & $\begin{array}{l}\text { Not known to be normally associated } \\
\text { with any disease }\end{array}$ \\
\hline 08 & M. parafortuitum & Soil & $\begin{array}{l}\text { Not known to be normally associated } \\
\text { with any disease }\end{array}$ \\
\hline 09 & M. sphagni & $\begin{array}{l}\text { Sphagnum vegetation in } \\
\text { moors }\end{array}$ & $\begin{array}{l}\text { Not known to be normally associated } \\
\text { with any disease }\end{array}$ \\
\hline 10 & M. tokaiense & Soil & $\begin{array}{l}\text { Not known to be normally associated } \\
\text { with any disease }\end{array}$ \\
\hline 11 & M. austroafricanum & South African waters & $\begin{array}{l}\text { Not known to be normally associated } \\
\text { with any disease }\end{array}$ \\
\hline 12 & M. diernhoferi & Soil in cattle field & $\begin{array}{l}\text { Not known to be normally associated } \\
\text { with any disease }\end{array}$ \\
\hline 13 & M. pulveris & House dust & $\begin{array}{l}\text { Not known to be normally associated } \\
\text { with any disease }\end{array}$ \\
\hline 14 & M. leprae & Soil (as CAN bacteria) & May or may not be pathogenic \\
\hline
\end{tabular}


TABLE 2: The pathogenic, primarily parasitic, mycobacteria

\begin{tabular}{|l|l|l|l|}
\hline $\begin{array}{l}\text { Sl. } \\
\text { No. }\end{array}$ & $\begin{array}{l}\text { Mycobacterium } \\
\text { spp. }\end{array}$ & Normal Ecosystem / Habitat & Pathogenicity \\
\hline 01 & M. marinum & $\begin{array}{l}\text { Diseased fish, humans. } \\
\text { Also in aquaria and swimming pools. }\end{array}$ & $\begin{array}{l}\text { Pathogenic to } \\
\text { humans }\end{array}$ \\
\hline 02 & M. kansasi & Strains isolated from water & $\begin{array}{l}\text { Pathogenic to } \\
\text { humans }\end{array}$ \\
\hline 03 & M. scrofulaceum & $\begin{array}{l}\text { Closed lesions of cervical lymphadenitis. } \\
\text { Occasionally in soil. }\end{array}$ & $\begin{array}{l}\text { Pathogenic to } \\
\text { humans }\end{array}$ \\
\hline 04 & M. avium & Frequently in pulmonary secretions & $\begin{array}{l}\text { Pathogenic to } \\
\text { humans }\end{array}$ \\
\hline 05 & M. fortuitum & $\begin{array}{l}\text { Pulmonary disease, local abscess. } \\
\text { Also in soil. }\end{array}$ & $\begin{array}{l}\text { Pathogenic to } \\
\text { humans }\end{array}$ \\
\hline 06 & M. chelonae & $\begin{array}{l}\text { Synovial tissue of knee \& abscess of gluteal } \\
\text { region. } \\
\text { Sputum. }\end{array}$ & $\begin{array}{l}\text { Pathogenic to } \\
\text { humans }\end{array}$ \\
\hline 07 & M. leprae & Tissues especially of limbs & $\begin{array}{l}\text { Pathogenic to } \\
\text { humans }\end{array}$ \\
\hline
\end{tabular}

TABLE 3: The environmental - host adapted, partially pathogenic, mycobacteria

\begin{tabular}{|l|l|l|l|}
\hline Sl. No. & Mycobacterium spp. & Normal Ecosystem / Habitat & Pathogenicity \\
\hline 01 & M. gordonae & $\begin{array}{l}\text { Human sputum. } \\
\text { Also in water taps and soil }\end{array}$ & Pathogenic to humans \\
\hline 02 & M. terrae & $\begin{array}{l}\text { Human sputum and gastric } \\
\text { lavage, Soil. }\end{array}$ & Pathogenic to humans \\
\hline 03 & M. aurum & $\begin{array}{l}\text { Occasionally in human } \\
\text { sputum, Soil. }\end{array}$ & Pathogenic to humans \\
\hline 04 & M. thermoresistible & Human sputum & Pathogenic to humans \\
\hline 05 & M. aichiense & $\begin{array}{l}\text { Human sputum. } \\
\text { Soil. }\end{array}$ & Pathogenic to humans \\
\hline 06 & M. flavescens & Normal flora in humans & Pathogenic to humans \\
\hline 07 & M. obuense & $\begin{array}{l}\text { Human sputum. } \\
\text { Soil. }\end{array}$ & Pathogenic to humans \\
\hline
\end{tabular}




\section{ORIGINAL ARTICLE}

TABLE 4: The environmental - host adapted, facultatively pathogenic mycobacteria, under immunosuppressed conditions

\begin{tabular}{|l|l|l|l|}
\hline Sl. No. & Mycobacterium spp. & $\begin{array}{l}\text { Normal Ecosystem / } \\
\text { Habitat }\end{array}$ & Pathogenicity \\
\hline 01 & M. gastri & $\begin{array}{l}\text { Human sputum and gastric } \\
\text { lavage, Soil. }\end{array}$ & Pathogenic to humans \\
\hline 02 & M. xenopi & Water taps \& soil & $\begin{array}{l}\text { Pathogenic to humans. } \\
\text { Waterborne nosocomial } \\
\text { outbreak }\end{array}$ \\
\hline 03 & M. fortuitum & Post-operative sterna wound & Pathogenic to humans \\
\hline
\end{tabular}

\section{REFERENCES:}

1. Cruickshank R, Duguid JP, Marmion BP, Swain RHA, editors. Medical Microbiology, $2^{\text {nd }}$ ed. Edinburgh: Churchill Livingstone; 1975.

2. Lawrence GW and Kubica GP. Mycobacteria. Bergey's Manual of Systematic Bacteriology 2nd ed. New York. PHA Mair, NS Sneath, JG Holt, Editors. Baltimore: William \& Wilkins; 1986. Pp. 1435-1457.

3. Banerjee P. Epidemiology of Human Leprosy and its correlation with Rat Leprosy. [Dissertation]. Kolkata, India: Calcutta University; 1989.

4. Parker MT and Duerden BI, Editors. Topley \& Wilson's Principles of Bacteriology, Virology and Immunology. 17th Ed., Vol II. Edward \& Arnold, London. 1990.

5. Kamala T, Herbert D, Venkatesan P, Prabhakar R and Paramasivan CN. Isolation and Identification of non-tuberculosis mycobacteria from the environment in the South Indian BCG Trial area. Proceedings of 13 th IWGMT Conference, Antwerp: 1992, Pp. 27.

6. Beenhouwer HD, de Rijk P, Douglas J and Portaels J. Diagnosis of Mycobacterial diseases, including leprosy, by PCR with nested primers on 16S-rRNA sequence. Proceedings of $13^{\text {th }}$ IWGMT Conference, Antwerp: 1992. Pp. 38.

7. Cross T and Goodfellow. Actinomycetes: Characteristics and Practical Importance. Taxonomy and Classification of the actinomycetes. Sykes and Skinner, editors, Academic Press, London; 1973. Pp 11-112.

8. Sen A. Biochemical and molecular probes to determine the relationship of chemoautotrophic nocardioform (CAN) bacteria isolated from infective leprosy tissues, to the leprosy bacillus (LB). [Thesis]. Kolkata, India: Jadavpur University; 1999. 